\title{
Hydrogen emissions from Erebus volcano, Antarctica
}

Yves Moussallam ${ }^{1}$-, Clive Oppenheimer ${ }^{1,2,3}{ }_{\text {- }}$ Alessandro Aiuppa ${ }^{4,5}$, Gaetano Giudice $^{5}$, Manuel Moussallam ${ }^{6}$ and Philip Kyle ${ }^{7}$

(1)

Department of Geography, University of Cambridge, Downing Place, Cambridge, CB2 3EN, UK

(2)

Le Studium, Institute for Advanced Studies, Orléans and Tours, France

(3)

L'Institut des Sciences de la Terre d'Orléans, l'Université d'Orléans, 1a rue de la Férollerie, 45071 Orléans Cedex 2, France

(4)

Dipartimento DiSTeM, Università di Palermo, Via archirafi 36, 90146 Palermo, Italy

(5)

Istituto Nazionale di Geofisica e Vulcanologia, Sezione di Palermo Via La Malfa, 153, 90146 Palermo, Italy

(6)

Institut Telecom-Telecom ParisTech-CNRS/LTCI, 37 rue Dareau, 75014 Paris, France

(7)

Department of Earth and Environmental Science, New Mexico Institute of Mining and Technology, 801 Leroy Place, Socorro, NM 87801, USA

\begin{abstract}
The continuous measurement of molecular hydrogen $\left(\mathrm{H}_{2}\right)$ emissions from passively degassing volcanoes has recently been made possible using a new generation of low-cost electrochemical sensors. We have used such sensors to measure $\mathrm{H}_{2}$, along with $\mathrm{SO}_{2}, \mathrm{H}_{2} \mathrm{O}$ and $\mathrm{CO}_{2}$, in the gas and aerosol plume emitted from the phonolite lava lake at Erebus volcano, Antarctica. The measurements were made at the crater rim between December 2010 and January 2011. Combined with measurements of the long-term $\mathrm{SO}_{2}$ emission rate for Erebus, they indicate a characteristic $\mathrm{H}_{2}$ flux of $0.03 \mathrm{~kg} \mathrm{~s}^{-1}\left(2.8 \mathrm{Mg} \mathrm{day}^{-1}\right)$. The observed $\mathrm{H}_{2}$ content in the plume is consistent with previous estimates of redox conditions in the lava lake inferred from mineral compositions and the observed $\mathrm{CO}_{2} / \mathrm{CO}$ ratio in the gas plume ( $\sim 0.9$ log units below the quartz-fayalite-magnetite buffer). These measurements suggest that $\mathrm{H}_{2}$ does not combust at the surface of the lake, and that $\mathrm{H}_{2}$ is kinetically inert in the gas/aerosol plume, retaining the signature of the high-temperature chemical equilibrium reached in the lava lake. We also observe a cyclical variation in the $\mathrm{H}_{2} / \mathrm{SO}_{2}$ ratio with a period of $\sim 10 \mathrm{~min}$. These cycles correspond to oscillatory patterns of surface motion of the lava lake that have been interpreted as signs of a pulsatory magma supply at the top of the magmatic conduit.
\end{abstract}

Keywords : Erebus volcano Hydrogen Magma redox conditions Lava lake Volcanic degassing 


\section{Introduction}

Hydrogen is one of the most abundant trace species in volcanic emissions (e.g. Giggenbach 1987; Oppenheimer et al. 2012) and is an essential participant in key redox reactions that take place in magmatic gases, e.g.

$$
\mathrm{H}_{2}+12 \mathrm{O}_{2}=\mathrm{H}_{2} \mathrm{O}
$$

and<smiles>[15SH2]O[SbH2]O[SbH2]</smiles>

At Erebus volcano, Antarctica, emissions to the atmosphere result from the sustained supply of gas via the persistently active lava lake and surrounding fumaroles. The gas composition of the plume provides valuable insights into redox conditions of the lava lake, assuming thermodynamic equilibrium is achieved between the gas phase and the melt. At Erebus volcano, the volcanic plume is mainly the result of passive degassing of the magma within the lava lake. Contrary to the conventional consideration that the redox state of a magma is buffered during decompression, recent chemical modelling of the gas phase in ascending magmas (Burgisser and Scaillet 2007; Burgisser et al. 2008) has suggested an evolution of the magma redox state during ascent, partly reflecting initial volatile contents. Measurement of redox-sensitive magmatic gas species such as molecular hydrogen will enable such models to provide better constrained "inversions" of surface geochemical signatures.

The recent development of highly portable and readily deployed multi-species gas sensing systems (Shinohara 2005; Aiuppa et al. 2005, 2006; De Vito et al. 2007) has enabled measurements of volcanic gas ratios for extended periods and in some cases operationally (Aiuppa et al. 2010a, b). Such multi-species approaches complement ultraviolet and infrared spectroscopic applications (Oppenheimer 2010) to enable measurement of abundances and fluxes of a range of gas species. Until very recently, there has not been a practical means for extended surveillance of hydrogen $\left(\mathrm{H}_{2}\right)$ abundance in dilute volcanic plumes (Aiuppa et al. 2011; Shinohara et al. 2011). Here, we use a "multi-gas" instrument incorporating a sensor to measure $\mathrm{H}_{2}$ in the plume emitted from the lava lake of Erebus volcano. Erebus is of particular interest because of the emerging evidence for redox change associated with magma ascent, with the most reducing conditions found in the lava lake itself (Oppenheimer et al. 2011). Despite challenging conditions at the summit crater, measurements were possible for several hours per day spanning a week. Our initial aims were to assess implications of the measurements for lava lake redox conditions and to identify any rapid variability in gas composition of the plume that would corroborate previous observation of cyclical behaviour of the lava lake (Oppenheimer et al. 2009).

\section{Methodology}

The measurements were made between 6 December 2010 and 3 January 2011 using a purpose-built multi-gas instrument and a $\mathrm{LI}-\mathrm{COR} \circledast \mathrm{LI}-840 \mathrm{CO}_{2}$ and $\mathrm{H}_{2} \mathrm{O}$ infrared analyser. The multi-gas instrument incorporated $\mathrm{H}_{2}, \mathrm{H}_{2} \mathrm{~S}$ and $\mathrm{SO}_{2}$ electrochemical sensors, a nondispersive infrared (NDIR) sensor for $\mathrm{CO}_{2}$, and a sensor for temperature and humidity 
measurements. The sampled gas is circulated via a miniature $12-\mathrm{V}$ rotary pump through the sensors (Aiuppa et al. 2011). The $\mathrm{H}_{2}, \mathrm{H}_{2} \mathrm{~S}$ and $\mathrm{SO}_{2}$ sensors produce an electrical current in response to the target gas entering the electrolyte and oxidizing or reducing the electrode. This current is proportional to the concentration of the target gas in the total gas volume. The electrochemical sensor for $\mathrm{SO}_{2}$ (City Technology, sensor type 3ST/F) has a calibration range of $0-30$ ppmv, an accuracy of $\pm 2 \%$, a repeatability of $1 \%$ and a resolution of $0.5 \mathrm{ppmv}$. The electrochemical sensor for $\mathrm{H}_{2}$ (City Technology, sensor type 3HYT) has a calibration range of $0-500$ ppmv, an accuracy of $\pm 5 \%$, a repeatability of $2 \%$ and a resolution of 2 ppmv. The $\mathrm{NDIR} \mathrm{CO}_{2}$ sensor (model Gascard II) is calibrated for 0-3,000 ppmv and has an accuracy $\pm 2 \%$ and a resolution of $0.8 \mathrm{ppmv}$. In addition to the gas sensors, temperature and relative humidity $(\mathrm{RH})$ sensors (Galltec) are mounted in the instrument, providing a measuring range of $0-100 \% \mathrm{RH}$ and an accuracy of $\pm 2 \%$. All sensors were housed inside a weatherproof box, with the ambient air sampled via Teflon tubing connected to a HEPA filter fed through an opening in the box. The sampled gas was ejected via an outlet likewise fed through a hole in the case. The sampled gas was heated to $\sim 30^{\circ} \mathrm{C}$ on its way through the first hose to prevent freezing and other problems related to the low ambient temperatures (below $-25^{\circ} \mathrm{C}$ ).

An on-board data-logger card in the multi-gas instrument captured measurements at a rate of $0.5 \mathrm{~Hz}$, while the LI 840 output was logged at $1 \mathrm{~Hz}$ via a netbook PC. Both instruments were always started simultaneously. The multi-gas instrument was recalibrated using standard gas mixtures in the laboratory (accurately measured by gas chromatography) before and after the campaign and showed very little drift $(<5 \%)$.

The LI-COR® LI-840 instrument was operated for intercomparison with the Gascard II and humidity sensors in the multi-gas unit. The LI-840 is a non-dispersive infrared gas analyser equipped with a dual wavelength, infrared detection system allowing measurements of $\mathrm{CO}_{2}$ and $\mathrm{H}_{2} \mathrm{O}$ in the gas phase in the range of $0-3,000$ ppmv and $0-80$ parts per thousand volume (pptv), respectively. The accuracy was better than $1.5 \%$ for both species and crosssensitivity is $<0.1$ ppmv $\mathrm{CO}_{2} /$ pptv $\mathrm{H}_{2} \mathrm{O}$ for $\mathrm{H}_{2} \mathrm{O}$ and $<0.0001$ pptv $\mathrm{H}_{2} \mathrm{O} / \mathrm{ppmv} \mathrm{CO}_{2}$ for $\mathrm{CO}_{2}$.

Both instruments were deployed intermittently on the crater rim of Erebus with their inlet filters placed side-by-side directly sampling the plume (Fig. 1). Measurements were possible when the plume was grounded and most data were collected at the "pump site" situated on the northern rim of the crater $\sim 220 \mathrm{~m}$ vertically above and $\sim 150 \mathrm{~m}$ horizontally from the lava lake. This site has consistently proved to be suitable for in situ plume sampling and sensing owing to the prevailing wind direction (Zreda-Gostynska et al. 1997; llyinskaya et al. 2010). Both instruments were powered by a 12-V DC battery, which sustained 6-10 h of unattended operation. 


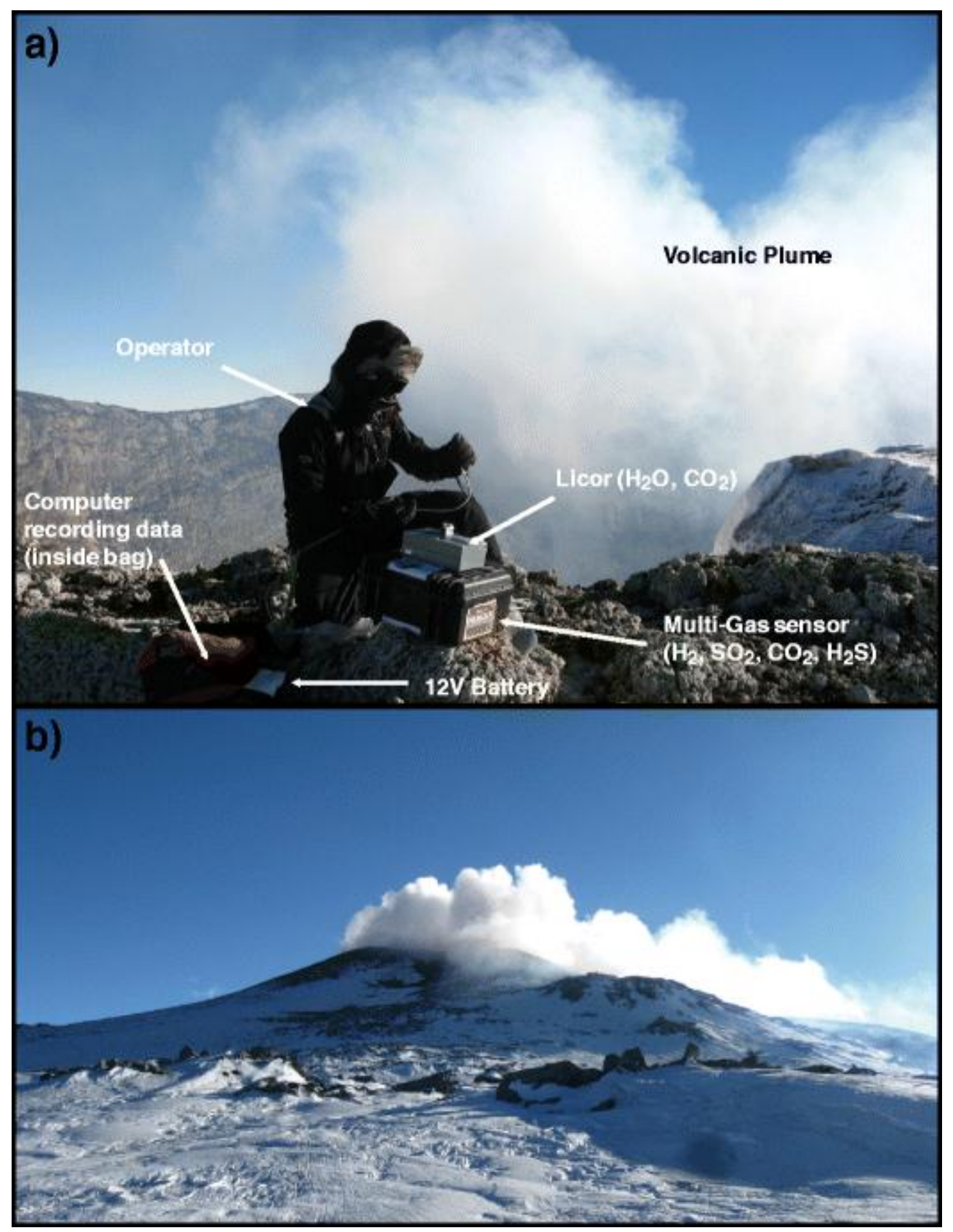

Fig. 1

a Typical field operating conditions during deployment of the LI 840 and multi-gas sensor at the crater rim. Gases are pumped through both instruments via narrow hoses connected to particle filters. b View of Erebus (looking south) during ideal plume sampling conditions on 26 December 2010. Turbulent airflow resulted in grounding of the plume at the sampling site

\section{Data processing}

Mixing ratios of $\mathrm{SO}_{2}, \mathrm{H}_{2} \mathrm{O}, \mathrm{CO}_{2}$ and $\mathrm{H}_{2}$ in the gas phase are retrieved (in parts per million volume) directly from the laboratory-calibrated sensors using the proprietary "840-500" software for the LI-840 and in-house software (developed at INGV Palermo) for the multi-gas 
instrument. The raw data collected by both instruments show a good correlation between all measured species. The good agreement between the $\mathrm{CO}_{2}$ measurements obtained by the multi-gas instrument and those obtained by the LI-840 provides a validation of the performance of the Gascard II sensor. Response times of the different sensors vary slightly but are all rapid, requiring a few seconds to approach maximum reading. Figure $\underline{2}$ shows an example of a typical dataset, recorded on 27 December 2010. All species' abundances are highly correlated, and there is little or no time lag between each sensor's response to increasing gas mixing ratios. Typical abundances measured at the crater rim range from 0.3 to 1.3 ppmv for $\mathrm{H}_{2}$ and $\mathrm{SO}_{2}, 400$ to 500 ppmv for $\mathrm{CO}_{2}$ and 800 ppmv for $\mathrm{H}_{2} \mathrm{O}$.

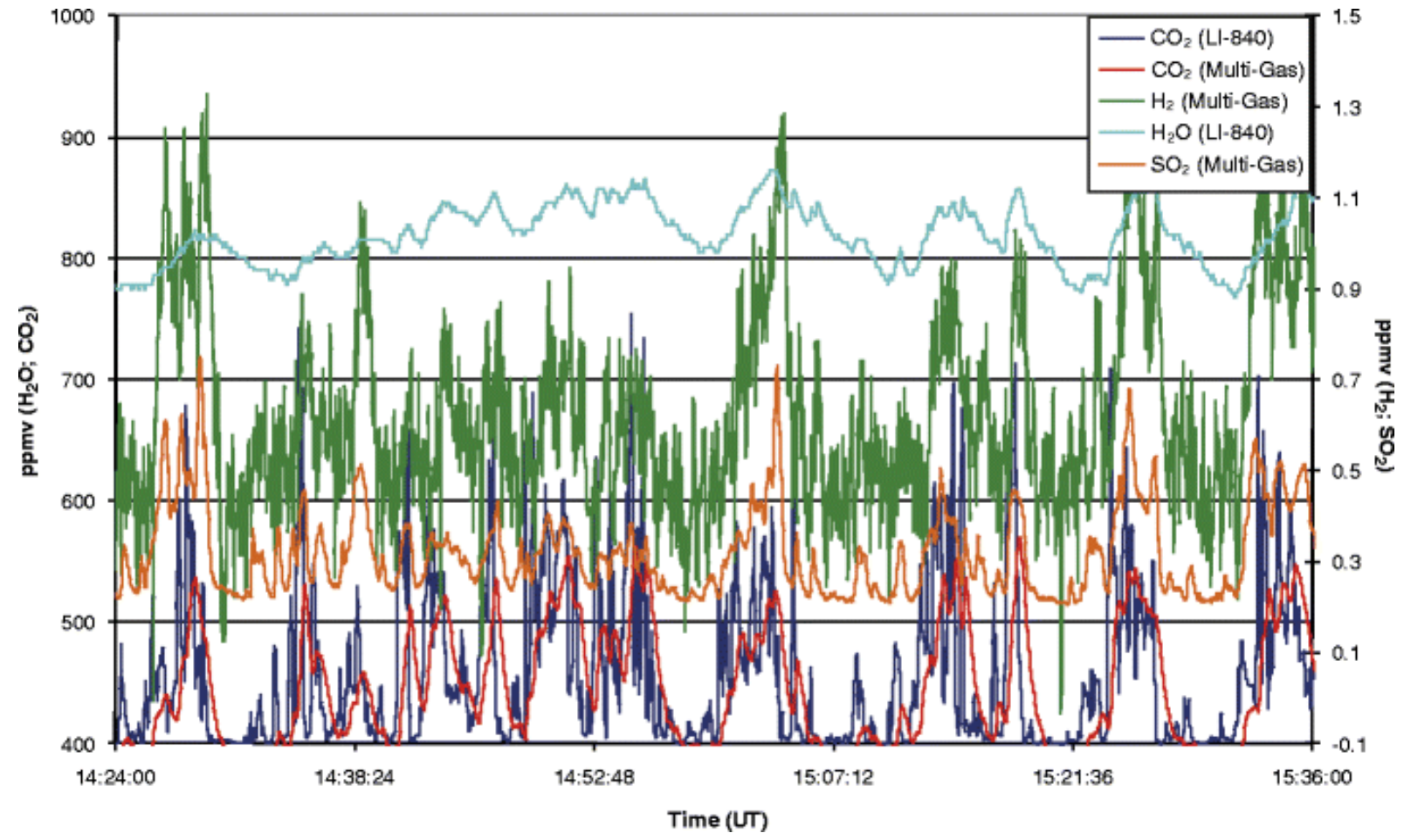

Fig. 2

Example of time series for gas mixing ratios obtained from both instruments (the multi-gas instrument and $\mathrm{LI} 840$ ). This 1-h-long time series is an extract from a 10-h-long run acquired at the crater rim on 27 December 2010. All gas abundances are reported in in parts per million volume

In order to convert the raw abundance data into reliable measurements, several processing steps were applied. Firstly, the small difference in response times between sensors was corrected for. Secondly, the sensor signal resulting from cross-sensitivity with other gases, characterised by laboratory measurements, was subtracted. The differences in response time for the different sensors were corrected by finding the lag times from correlation analysis of the various time series. Laboratory tests were performed using a set of gas standards circulated through the multi-gas instrument in order to determine the cross-sensitivity of the hydrogen sensor to other species. Carbon monoxide was a particular concern because of its abundance in the Erebus gas/aerosol plume (Wardell et al. 2004; Oppenheimer and Kyle 2008). Its effect was tested for a range of $\mathrm{CO}$ from 7 to $500 \mathrm{ppmv}$. Mixed $\mathrm{CO}$ and $\mathrm{H}_{2}$ gas calibrations were also carried out. These tests revealed a constant $4 \%$ cross-sensitivity of the $\mathrm{H}_{2}$ sensor due to the presence of $\mathrm{CO}$. The $\mathrm{H}_{2}$ sensor was found not to be sensitive to 
$\mathrm{H}_{2} \mathrm{O}, \mathrm{CO}_{2}$ or $\mathrm{SO}_{2}$. Although there was no $\mathrm{CO}$ sensor in the multi-gas instrument, an estimate of $\mathrm{CO}$ abundances can be made, point-by-point, from measured $\mathrm{CO}_{2}$ abundance and using a $\mathrm{CO}_{2} / \mathrm{CO}$ molar ratio of $13 \pm 1$ obtained from open-path FTIR spectroscopic measurements (Oppenheimer et al. 2009; llanko personal communication). At each point, $4 \%$ of the estimated $\mathrm{CO}$ value was subtracted from the $\mathrm{H}_{2}$ signal to correct for the cross-sensitivity (Fig. 3).
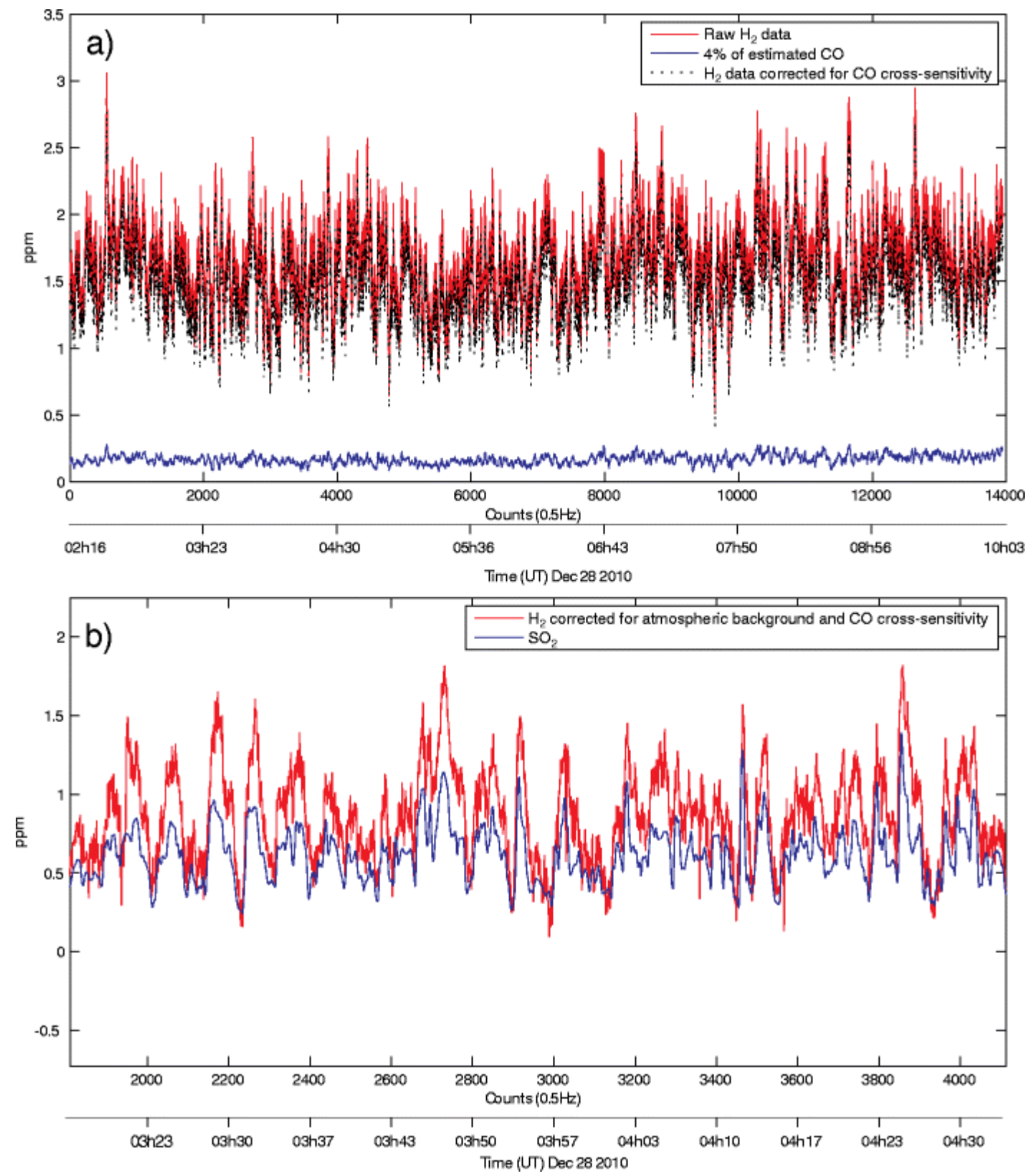

Fig. 3

a Raw (red trace) and corrected (dashed trace) time series for $\mathrm{H}_{2}$. The corrected time series is obtained by estimating the signal that would be due to presence of $\mathrm{CO}$ in the plume (blue trace). The abundance of $\mathrm{CO}$ has been estimated from the corresponding Gascard II $\mathrm{CO}_{2}$ time series, from which a constant background atmospheric value of $387.5 \mathrm{ppmv}$ has been subtracted, and a $\mathrm{CO}_{2} / \mathrm{CO}$ molar ratio of 13 (from Oppenheimer et al. 2009). $\mathrm{b} \mathrm{H}_{2}$ and $\mathrm{SO}_{2}$ time series after correction for atmospheric background $\mathrm{H}_{2}$ and $\mathrm{CO}$ cross-sensitivity and after alignment of both times series using an offset calculated from the maximum correlation factor between the time series 


\section{Results}

Useful data were only acquired during favourable winds that resulted in grounding of the plume at the crater rim (Fig. 1b). We obtained $25 \mathrm{~h}$ of good quality observations at a sample rate of $0.5 \mathrm{~Hz}$ over the $180 \mathrm{~h}$ of data collection. As well as the variable weather conditions, delays in stabilising the internal temperature of the multi-gas instrument were also responsible for the limited collection time. It is worth noting that Strombolian eruptions, which are occasionally observed at Erebus (Aster et al. 2003; Dibble et al. 2008), did not occur during the acquisition of this dataset; only the "passive" plume emitted from the lava lake was sampled. Figure 4 shows 12 scatter plots for measurements recorded during the last week of December 2010, which offered the best conditions for plume sampling. Results from 6 days of data yield a daily mean $\mathrm{H}_{2} / \mathrm{SO}_{2}$ molar ratio between 1.38 and 1.52 (Fig. 4a); the average ratio for the whole week being 1.44. Scatter plots for the $\mathrm{CO}_{2}$ and $\mathrm{SO}_{2}$ measurements yield $\mathrm{CO}_{2} / \mathrm{SO}_{2}$ molar ratios varying between 36 and 45 (Fig. $4 \mathrm{~b}$ ), with the week's average being 40. We neglect the $\mathrm{CO}_{2} / \mathrm{SO}_{2}$ ratio obtained for 3 January which shows much higher variability, which we ascribe to contamination from nearby fumaroles. The intercept of first order linear regression through the scatter plots of $\mathrm{H}_{2}$ vs. $\mathrm{SO}_{2}$ and $\mathrm{CO}_{2}$ vs. $\mathrm{SO}_{2}$ should correspond to the atmospheric background $\mathrm{H}_{2}$ and $\mathrm{CO}_{2}$ abundances, respectively (since ambient $\mathrm{SO}_{2}$ is very low, less than $10 \mathrm{pptv}$ ). In fact, we find values for ambient $\mathrm{H}_{2}$ between 1.06 and 0.42 ppmv and background $\mathrm{CO}_{2}$ values between 433 and 385 ppmv. These are both good approximations to expected atmospheric background abundances for the two gases. For instance, measurements from December 2010 at the South Pole weather station (available at http://www.esrl.noaa.gov/) indicate a mixing ratio of $387.5 \mathrm{ppmv}$ for $\mathrm{CO}_{2}$ and 0.54 ppmv for $\mathrm{H}_{2}$. This station is the closest Antarctic research station routinely measuring atmospheric gas abundances at altitude $(2,900 \mathrm{~m}$ a.s.l, c.f. the altitude of the pump site of $\sim 3,700 \mathrm{~m}$ ). A test run using the multi-gas instrument on 7 December carried out near Lower Erebus hut ( $2 \mathrm{~km}$ from the crater) also yielded stable $\mathrm{H}_{2}$ readings of $\sim 0.5 \mathrm{ppmv}$, though $\mathrm{CO}_{2}$ readings fluctuated between 400 and 350 ppmv with temperature drift during acquisition. These estimates of the ambient mixing ratios of the two gases give further confidence in the performance of the multi-gas instrument sensors. While $\mathrm{H}_{2} \mathrm{O}$ was being recorded simultaneously by both the LICOR and multi-gas instruments, changes in the ambient atmospheric humidity, the influence of nearby low-temperature fumaroles and conceivably absorption of $\mathrm{H}_{2} \mathrm{O}$ on tubing and filters precluded reliable retrieval of water content of the plume. 

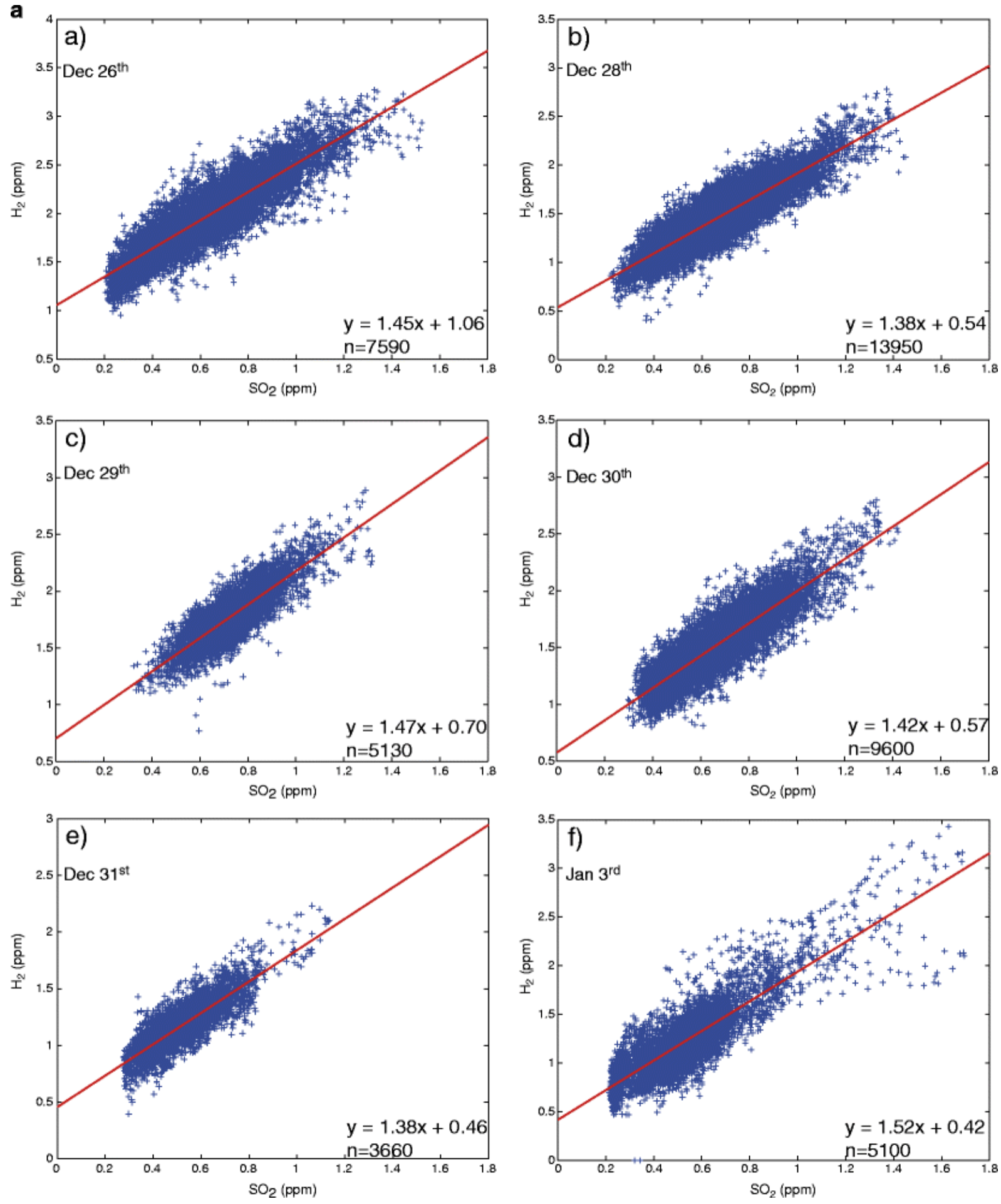

Fig. 4

a $\mathrm{H}_{2}-\mathrm{SO}_{2}$ and $\mathrm{b} \mathrm{CO} \mathrm{CO}_{2}-\mathrm{SO}_{2}$ scatter plots from 6 days of sampling of the Erebus plume under favourable conditions. a 11:20 to 16:33, 26 December 2010, UTC. b 02:16 to 10:01, 28 December 2010, UTC. c 11:07 to 13:58, 29 December 2010, UTC. d 06:25 to 11:45, 30 December 2010, UTC. e 04:10 to 06:12, 31 December 2010, UTC. f 22:42 to 01:32, 3 January 2011, UTC. Regression lines are shown in red and corresponding parameters are displayed on the lower right corner of each plot 
Further inspection of our dataset reveals small but clear variations in the retrieved gas ratios which appear cyclical. Figure 5 shows the evolution of the $\mathrm{H}_{2} / \mathrm{SO}_{2}$ and $\mathrm{SO}_{2} / \mathrm{CO}_{2}$ ratios for 23 min on 26 December. Three complete cycles of about 7 to 8 min length can clearly be identified in both time series. The $\mathrm{H}_{2} / \mathrm{SO}_{2}$ ratio for $\sim 3 \mathrm{~h}$ on 3 January 2011 is also reported on this figure and shows 15 cycles of about $10 \mathrm{~min}$. Figure 5 also presents the corresponding pseudo-periodogram obtained for these $\sim 3 \mathrm{~h}$ using a continuous Morlet wavelet transform analysis (Goupillaud et al. 1984) of the time series. The pseudo-periodogram shows a strong transform modulus with a cycle of 8 to $12 \mathrm{~min}$. Similar pseudo-periodograms have been produced for all the time series for which data are presented in Fig. 4, and all reveal cycles with periods of 7 to $14 \mathrm{~min}$. In addition, some pseudo-periodograms show weaker signal strength at a shorter period of 3 to $5 \mathrm{~min}$. 

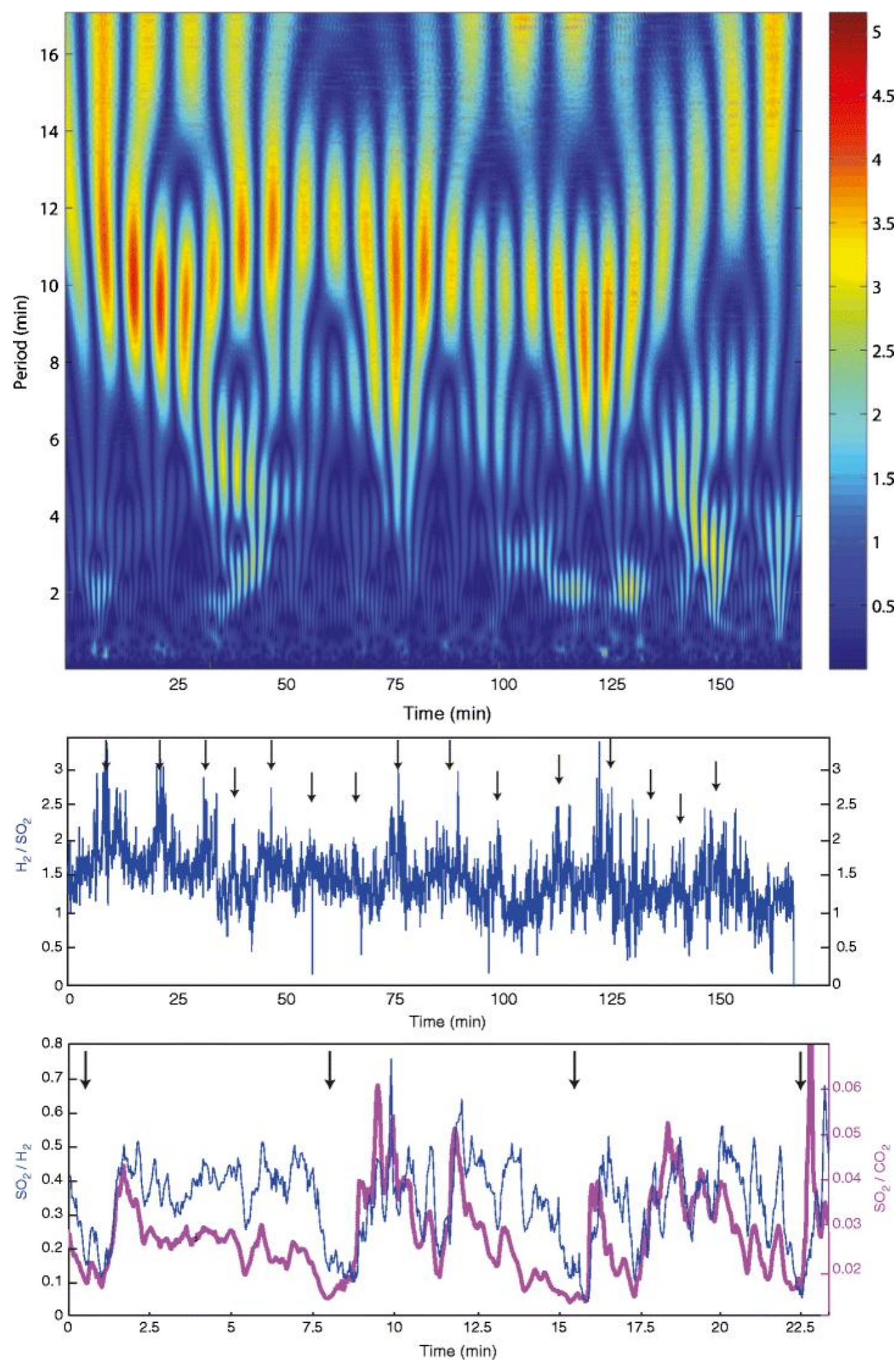

Fig. 5

Morlet wavelet transform pseudo-periodogram computed from a 3-h time series of the $\mathrm{H}_{2} / \mathrm{SO}_{2}$ ratio obtained from a 10-h-long run of the multi-gas instrument on 3 January 2011. Note the strong transform modulus emerging steadily at a period of $\sim 10 \mathrm{~min}$. The central panel shows the same 3-h time series of the evolution of the $\mathrm{H}_{2} / \mathrm{SO}_{2}$ ratio in which $\sim 10$-min cycles can be observed. Black arrows indicate the peak in $\mathrm{H}_{2} / \mathrm{SO}_{2}$ ratio of each cycle. The lower diagram shows the evolution of the $\mathrm{SO}_{2} / \mathrm{H}_{2}$ and $\mathrm{SO}_{2} / \mathrm{CO}_{2}$ ratios for the first 1,400 s ( 23 $\left.\mathrm{min}\right)$ of a time series obtained from an 8-h-long run of the multi-gas instrument on 26 December 2010. This lower diagram shows three complete cycles of $\sim 8 \mathrm{~min}$ each and shows reasonably clearly that $\mathrm{SO}_{2} / \mathrm{H}_{2}$ follows $\mathrm{SO}_{2} / \mathrm{CO}_{2}$. Black arrows indicate peak in $\mathrm{H}_{2} / \mathrm{SO}_{2}$ ratio of each cycle 
Pseudo-periodograms were produced for the $\mathrm{CO}_{2} / \mathrm{SO}_{2}$ and $\mathrm{CO}_{2} / \mathrm{H}_{2}$ ratio time series and reveal similar periodicities. The $\mathrm{CO}_{2} / \mathrm{H}_{2}$ ratios vary mostly between 20 and 35 . Lower and upper extremes are approximately 15 and 50 , respectively. The periodicity is noteworthy since it suggests preservation of a source signature despite the passage of the plume within the crater (and the possibility for mixing and homogenization of the time-varying signal), from the lava lake to the pump site. Time series of the $\mathrm{SO}_{2} / \mathrm{H}_{2}$ and $\mathrm{SO}_{2} / \mathrm{CO}_{2}$ ratios were constructed using background $\mathrm{H}_{2}$ and $\mathrm{CO}_{2}$ atmospheric values determined by the intersection of the linear regression with the $\mathrm{H}_{2}$ or $\mathrm{CO}_{2}$-axis for each day (Fig. 4) except when that intercept was higher than the lowest measured $\mathrm{H}_{2}$ or $\mathrm{CO}_{2}$ value, in which case this lowest $\mathrm{H}_{2}$ or $\mathrm{CO}_{2}$ value was used as the background.

\section{Discussion}

\section{$\mathrm{H}_{2}$ contribution to the Antarctic atmosphere from Erebus}

We have estimated the $\mathrm{H}_{2}$ flux from Erebus volcano using the time-averaged (over approximately a decade of observations) $\mathrm{SO}_{2}$ flux of $0.71 \pm 0.3 \mathrm{~kg} \mathrm{~s}^{-1}$ (Sweeney et al. 2008) and the measured $\mathrm{H}_{2} / \mathrm{SO}_{2}$ ratio. Using our mean $\mathrm{H}_{2} / \mathrm{SO}_{2}$ molar ratio of 1.44 (equivalent to a $\mathrm{H}_{2} / \mathrm{SO}_{2}$ mass ratio of 0.045 ), we estimate the mean $\mathrm{H}_{2}$ flux at Erebus volcano as $0.03 \mathrm{~kg} \mathrm{~s}^{-1}$ $\left(2.8 \mathrm{Mg} \mathrm{day}^{-1}\right)$. Note, however, that the $\mathrm{SO}_{2}$ emission rate itself fluctuates cyclically (from 0.17 to $0.89 \pm 0.20 \mathrm{~kg} \mathrm{~s}^{-1}$ in December 2005; Boichu et al. 2010). This estimated $\mathrm{H}_{2}$ flux from Erebus is the largest recorded point source of $\mathrm{H}_{2}$ to the Antarctic atmosphere. The Erebus source amounts to $\sim 1 \mathrm{Gg} \mathrm{a}^{-1}$ of $\mathrm{H}_{2}$ corresponding to 0.004 to $0.02 \%$ of the total global anthropogenic emission (the global anthropogenic emission of $\mathrm{H}_{2}$ from the use of fossil fuels is estimated at 5 to $25 \mathrm{Tg} \mathrm{a}^{-1}$ ) (Novelli et al. 1999). For comparison, the hydrogen flux at Mt. Etna has been estimated at $\sim 0.00065 \mathrm{Tg} \mathrm{a}^{-1}$ (Aiuppa et al. 2011).

\section{Oxidation state of the Erebus lava lake}

Based on a mean bulk plume $\mathrm{SO}_{2} / \mathrm{H}_{2} \mathrm{O}$ molar ratio of 0.023 obtained by FTIR spectroscopy (Oppenheimer et al. 2009), we can convert the mean multi-gas-measured $\mathrm{H}_{2} / \mathrm{SO}_{2}$ ratio to an $\mathrm{H}_{2} / \mathrm{H}_{2} \mathrm{O}$ molar ratio of 0.033 . From this ratio, we can calculate the corresponding oxygen fugacity based on the redox reaction in Eq. (1).

The equilibrium constant, $\mathrm{K}$, for this reaction is given by:

$$
K=f_{2} \times\left(\mathrm{fO}_{2}\right){ }_{12} f_{\mathrm{H}_{2} \mathrm{O}}
$$

where $\mathrm{fH}_{2}=\gamma \mathrm{H}_{2} \times \mathrm{PH}_{2} ; \mathrm{fO}_{2}=\mathrm{YO}_{2} \times \mathrm{PO}_{2} ; \mathrm{H}_{2} \mathrm{O}=\mathrm{H}_{2} \mathrm{O} \times P_{\mathrm{H}_{2} \mathrm{O}}$

with $P=X i \times P$

and where $f_{i}$ is the fugacity of the ith species, $Y_{i}$ is the fugacity coefficient of the ith species, $P_{i}$ is the partial pressure of the ith species, $x_{i}$ is the mole fraction of the ith species and $P$ is the total gas pressure.

This yields:

$$
\left(\mathrm{fO}_{2}\right)_{12}=K \times \mathrm{fH}_{2} \mathrm{O} \mathrm{fH}_{2}=K \mathrm{KH}_{2} \mathrm{O} \times X \mathrm{H}_{2} \mathrm{O} \times \mathrm{P}_{Y \mathrm{H}_{2}} \times X \mathrm{H}_{2} \times P
$$


and therefore

$\mathrm{fO}_{2}=\left(K Y \mathrm{H}_{2} \mathrm{O} \times X \mathrm{H}_{2} \mathrm{O} Y \mathrm{H}_{2} \times X \mathrm{H}_{2}\right) 2$.

At atmospheric pressure, the fugacity of a gas is equal to its partial pressure (assuming ideal behaviour), therefore $\mathrm{YH}_{2} \mathrm{O} / \mathrm{YH}_{2}=1$. The equilibrium constant was calculated using MaierKelly coefficients specific for each species and obtained here from the Supcrt92 software (Johnson et al. 1992). At $\mathrm{T}=1,273 \mathrm{~K}$ (the most widely accepted temperature of the lava lake), $\mathrm{K}=3.72 \times 10^{-8}$, the logfO ${ }_{2}$ is equivalent to $\triangle \mathrm{QFM}=-0.92$ (using a $\mathrm{H}_{2} / \mathrm{SO}_{2}$ ratio of 1.44 , where QFM refers to the quartz-fayalite-magnetite buffer, and where $\triangle Q F M=\operatorname{logfO} O_{2}-\operatorname{logfO} \mathrm{O}_{2}$ of QFM). Using the obtained oxygen fugacity and prior measurements (Oppenheimer et al. 2009), we can recalculate the composition of the Erebus plume to include $\mathrm{H}_{2}$ and the expected abundance of $\mathrm{H}_{2} \mathrm{~S}$ (Table 1, first column). Note that, in the table, $\mathrm{H}_{2} \mathrm{~S}$ is estimated based on the gas redox properties calculated using the "Dcompress" software from Burgisser et al. (2008) though it has not been detected at Erebus despite multiple attempts (Oppenheimer and Kyle 2008).

Table 1

Estimated composition of the Erebus plume in mole percent and molecular ratios for given species pairs

\begin{tabular}{|l|l|l|l|}
\hline & Mean & Top of cycle & Bottom of cycle \\
\hline & mol\% & \multicolumn{2}{l|}{} \\
\hline & 44.00 & 34.86 & 47.25 \\
\hline $\mathrm{CO}_{2}$ & 47.84 & 57.62 & 43.37 \\
\hline $\mathrm{H}_{2} \mathrm{O}$ & 1.10 & 1.39 & 0.94 \\
\hline $\mathrm{SO}_{2}$ & 3.30 & 2.61 & 3.54 \\
\hline $\mathrm{CO}$ & 0.46 & 0.56 & 0.42 \\
\hline $\mathrm{HCl}$ & 1.16 & 1.39 & 1.05 \\
\hline $\mathrm{HF}$ & 1.58 & 1.39 & 1.89 \\
\hline $\mathrm{H}_{2}$ & 0.01 & 0.01 & 0.01 \\
\hline $\mathrm{OCS}$ & 0.55 & 0.16 & 1.53 \\
\hline $\mathrm{H}_{2} \mathrm{~S}$ & mol/mol & \\
\hline & 13.33 & 13.33 & 13.33 \\
\hline $\mathrm{CO}_{2} / \mathrm{CO}$ & 0.02 & 0.02 & 0.02 \\
\hline $\mathrm{SO}_{2} / \mathrm{H}_{2} \mathrm{O}$ & 1.44 & 1.00 & 2.00 \\
\hline $\mathrm{H}_{2} / \mathrm{SO}_{2}$ & 40.00 & 25.00 & 50.00 \\
\hline $\mathrm{CO}_{2} / \mathrm{SO}_{2}$ & 2.01 & 8.72 & 0.62 \\
\hline $\mathrm{SO}_{2} / \mathrm{H}_{2} \mathrm{~S}$ & -11.90 & -11.63 & -12.14 \\
\hline $\log _{\left(\mathrm{fO}_{2}\right) \text { at } 1,000{ }^{\circ} \mathrm{C}}$ & -0.92 & -0.65 & -1.16 \\
\hline $\mathrm{Della} \mathrm{QFM}$ & & \\
\hline
\end{tabular}

The $\mathrm{CO}_{2} / \mathrm{CO}$ and $\mathrm{SO}_{2} / \mathrm{H}_{2} \mathrm{O}$ molar ratios are obtained from Oppenheimer et al. (2009) as $\mathrm{HCl} / \mathrm{CO}$, $\mathrm{HF} / \mathrm{CO}$ and OCS/CO ratios are used to estimate the plume composition in mole percent. The $\mathrm{H}_{2} / \mathrm{SO}_{2}$ and $\mathrm{CO}_{2} / \mathrm{SO}_{2}$ molar ratios are obtained from the multi-gas instrument measurements and the $\mathrm{SO}_{2} / \mathrm{H}_{2} \mathrm{~S}$ molar ratio is calculated using the Dcompress software (Burgisser et al. 2008). The top of cycle 
composition corresponds to the mixed plume composition of Oppenheimer et al. (2009), while the bottom of cycle composition corresponds to the conduit gas composition of Oppenheimer et al. (2009)

The oxidation state of the phonolite magma in the persistent lava lake of Erebus volcano has been estimated by several techniques. Kelly et al. (2008) used mineral chemistry to estimate an oxidation state of $\triangle Q F M=-0.9$ using the QUILF program (Andersen et al. 1993) and a temperature of $1,000^{\circ} \mathrm{C}$. Oppenheimer and Kyle (2008) and Oppenheimer et al. (2011) used the $\mathrm{CO}_{2} / \mathrm{CO}$ ratio obtained using FTIR spectroscopy (and the same temperature) to estimate the oxidation state at $\triangle Q F M=-0.9$ to -0.88 . Both of these estimates are essentially identical to our mean $\triangle Q F M=-0.92$. It should be noted however that our new estimate of the oxidation state is not entirely independent as we used the $\mathrm{SO}_{2} / \mathrm{H}_{2} \mathrm{O}$ ratio previously measured by FTIR spectroscopy in our calculation.

The presence of $\mathrm{H}_{2}$ in the volcanic plume suggests that $\mathrm{H}_{2}$ is not burning at the interface between the lava lake and the atmosphere as has been observed, for instance, at Killauea's lava lake (Cruikshank et al. 1973). The correspondence of computed redox conditions for the lava lake also indicates that the $\mathrm{H}_{2}$ abundance at the crater rim corresponds to the hightemperature equilibrium with the lava lake as hypothesized by Martin et al. (2009) and experimentally verified at Etna by Aiuppa et al. (2011). If any $\mathrm{H}_{2}$ is oxidizing in the plume (e.g. to form $\mathrm{HO}_{x}$ radicals), it is only in minor amounts.

\section{Periodicity and magma supply to the lake}

From the time series, the $\mathrm{H}_{2} / \mathrm{SO}_{2}$ molar ratio varies mostly between 1 and 2 for all 6 days while the $\mathrm{CO}_{2} / \mathrm{SO}_{2}$ molar ratio varies mostly between 25 and 50 . These upper and lower values can be attributed to two end-member compositions associated with a cyclic dynamic behaviour of the lake (Table 1). This quasi-periodic behaviour has been recognised in the velocity field of the lava lake surface motion, the heat loss of the lava lake, the $\mathrm{SO}_{2} / \mathrm{CO}_{2}$ and $\mathrm{HCl} / \mathrm{CO}$ gas ratios (Oppenheimer et al. 2009), the $\mathrm{SO}_{2}$ flux (Boichu et al. 2010) and lidar observation of the rising and falling lava lake surface (Jones et al. 2010, 2011). All these observations reveal cycles of between roughly 8 and $18 \mathrm{~min}$. These have been interpreted as consequences of an episodic arrival of magma into the lava lake, which exsolves a water-rich end-member gas composition (Oppenheimer et al. 2009; Boichu et al. 2010).

The terms "top" and "bottom" of the cycle are adopted here to echo the previous literature (Oppenheimer et al. 2009); the "top of cycle" refers to high $\mathrm{SO}_{2} / \mathrm{CO}_{2}$ ratio, faster lake motion and higher lake level, and, as shown in Fig. 5, corresponds to high $\mathrm{SO}_{2} / \mathrm{H}_{2}$. This composition is calculated using an $\mathrm{H}_{2} / \mathrm{SO}_{2}$ molar ratio of 1 and $\mathrm{SO}_{2} / \mathrm{H}_{2} \mathrm{O}$ molar ratio of 0.0242 from the "mixed plume" composition of Oppenheimer et al. (2009), which corresponds to measurements during vigorous convection of the lava lake, while the "bottom of cycle" composition is calculated using an $\mathrm{H}_{2} / \mathrm{SO}_{2}$ ratio of 2 and $\mathrm{SO}_{2} / \mathrm{H}_{2} \mathrm{O}$ gas ratios of 0.0218 from the "conduit gas" composition of Oppenheimer et al. (2009). The difference between the two end-member compositions is quite significant in terms of redox state, representing $\Delta \mathrm{QFM}=-0.65$ at the "top of the cycle" and $\Delta \mathrm{QFM}=-1.16$ at the "bottom of the cycle", assuming no change in temperature.

Considering that the "tops" of the cycles are marked by increases in lake level, surface motion and $\mathrm{SO}_{2}$ flux, Oppenheimer et al. (2009) and Boichu et al. (2010) suggested that they are associated with the arrival of foaming magma batches in the lava lake (still exsolving water at near atmospheric pressure). We now observe that the tops of the cycle are 
consistently associated with significantly more oxidized conditions ( $\triangle \mathrm{QFM}=-0.65)$ than the "bottoms" of the cycles ( $\triangle \mathrm{QFM}=-1.16)$. This differential pattern in oxidation state is also apparent in subtle cyclic variations in $\mathrm{CO}_{2} / \mathrm{CO}$ ratio reported in Burgisser et al. (2012). If the top of the cycles is indeed associated with the influx of rising magma batches, then these batches appear to be releasing gas whose composition is a relic of chemical equilibrium acquired at some depth. This signature may be preserved as a result of rapid ascent of the magma batch (i.e. fast with respect to the kinetics of redox reactions such as [1] and [2]). The dichotomy we identify between the oxidized top and reduced bottom of the cycles therefore provides further empirical evidence for redox stratification in the Erebus plumbing system as discussed in Oppenheimer et al. (2011) and Burgisser et al. (2012) and as hypothesized from a more general standpoint by Burgisser and Scaillet (2007).

\section{Conclusion}

In situ measurements of the gas plume emitted from the lava lake of Erebus volcano by means of a multi-gas sensing instrument indicate that the hydrogen abundance in the magmatic gas phase is around $1.6 \mathrm{~mol} \%$. These measurements constrain the oxidation state of the lava lake to $\triangle Q F M=-0.9$ log units, consistent with previous estimates; provide strong evidence that hydrogen burning is not prevalent at the surface of the lake; and that hydrogen is at least largely kinetically inert in the gas/aerosol plume rising in the crater. The hydrogen flux to the atmosphere from the summit of Erebus is estimated at $2.8 \mathrm{Mg} \mathrm{day}^{-1}$. A strong $\sim 10$-min cyclicity in the proportions of $\mathrm{H}_{2}$ and other species in the plume infers corresponding redox state variations and points to a pulsatory supply of magma to the lava lake. The more oxidized signature of the magma episodically entering the lake provides strong empirical evidence of a redox stratification in the shallow plumbing system, as has been hypothesized by previous numerical models.

\section{Acknowledgments}

This research was supported by grant ANT-0838817 from the Office of Polar Programs (National Science Foundation) and grant 202844 ("DEMONS") from the European Research Council (FP7). YM was additionally supported by the University of Cambridge Home and EU Scholarship Scheme, and CO acknowledges funding from the National Centre for Earth Observation (Theme 6: "Dynamic Earth and Geohazards"). We are grateful to Hiroshi Shinohara and Eliza Calder for their constructive reviews of the original work. We also thank Tehnuka Ilanko, Bill Mclntosh, Nial Peters and Aaron Curtis for assistance on Erebus.

\section{References}

Aiuppa A, Bertagnini A, Métrich N, Moretti R, Di Muro A, Liuzzo M, Tamburello G (2010a) A model of degassing for Stromboli volcano. Earth Planet Sci Lett 295:195204, 16/j.epsl.2010.03.040

Aiuppa A, Burton M, Caltabiano T, Giudice G, Guerrieri S, Liuzzo M, Murè F, Salerno $\mathrm{G}$ (2010b) Unusually large magmatic $\mathrm{CO}_{2}$ gas emissions prior to a basaltic paroxysm. Geophys Res Lett 37. doi:10.1029/2010GL043837

Aiuppa A, Federico C, Giudice G, Gurrieri S, Valenza M (2006) Hydrothermal buffering of the $\mathrm{SO}_{2} / \mathrm{H}_{2} \mathrm{~S}$ ratio in volcanic gases: evidence from La Fossa Crater fumarolic field, Vulcano Island. Geophys Res Lett 33:5, doi:10.1029/2006GL027730 
Aiuppa A, Federico C, Giudice G, Gurrieri S (2005) Chemical mapping of a fumarolic field: La Fossa Crater, Vulcano Island (Aeolian Islands, Italy). Geophys Res Lett 32:4, doi:10.1029/2005GL023207

Aiuppa A, Shinohara H, Tamburello G, Giudice G, Liuzzo M, Moretti R (2011) Hydrogen in the gas plume of an open-vent volcano, Mount Etna, Italy. J Geophys Res 116:8, doi:10.1029/2011JB008461

Andersen DJ, Lindsley DH, Davidson PM (1993) QUILF: a pascal program to assess equilibria among Fe-Mg-Mn-Ti oxides, pyroxenes, olivine, and quartz. Comput Geosci 19:1333-1350. doi:10.1016/0098-3004(93)90033-2

Aster R, Mah S, Kyle P, McIntosh W, Dunbar N, Johnson J, Ruiz M, McNamara S (2003) Very long period oscillations of Mount Erebus volcano. J Geophys Res 108. doi:10.1029/2002JB002101

Boichu M, Oppenheimer C, Tsanev V, Kyle P (2010) High temporal resolution $\mathrm{SO}_{2}$ flux measurements at Erebus volcano, Antarctica. J Volcanol Geotherm Res 190:325-336. doi:10.1016/j.jvolgeores.2009.11.020

Burgisser, A., Alletti, M., Oppenheimer, C. (2012) Inverse modelling of gas chemistry measurements. Goldschmidt Conference, Prague, Czech Republic

Burgisser A, Scaillet B, Harshvardhan B (2008) Chemical patterns of erupting silicic magmas and their influence on the amount of degassing during ascent. J Geophys Res 113:14, doi:10.1029/2008JB005680

Burgisser A, Scaillet B (2007) Redox evolution of a degassing magma rising to the surface. Nature 445:194-197

Cruikshank DP, Morrison D, Lennon K (1973) Volcanic gases: hydrogen burning at Kilauea Volcano, Hawaii. Science 182:277-279. doi:10.1126/science.182.4109.277

De Vito S, Massera E, Quercia L, Di Francia G (2007) Analysis of volcanic gases by means of electronic nose. Sensors Actuators B Chem 127:36-41.

doi:16/j.snb.2007.07.042

Dibble RR, Kyle PR, Rowe CA (2008) Video and seismic observations of Strombolian eruptions at Erebus volcano, Antarctica. J Volcanol Geotherm Res 177:619-634

Giggenbach WF (1987) Redox processes governing the chemistry of fumarolic gas discharges from White Island, New Zealand. Appl Geochem 2:143-161. doi:10.1016/0883-2927(87)90030-8

Goupillaud P, Grossmann A, Morlet J (1984) Cycle-octave and related transforms in seismic signal analysis. Geoexploration 23:85-102. doi:10.1016/00167142(84)90025-5

Ilyinskaya E, Oppenheimer C, Mather TA, Martin RS, Kyle PR (2010) Size-resolved chemical composition of aerosol emitted by Erebus volcano, Antarctica. Geochem Geophys Geosyst 11. doi:10.1029/2009GC002855 
Johnson JW, Oelkers EH, Helgeson HC (1992) SUPCRT92: a software package for calculating the standard molal thermodynamic properties of minerals, gases, aqueous species, and reactions from 1 to 5000 bar and 0 to $1000{ }^{\circ} \mathrm{C}$. Comput Geosci 18:899-947. doi:16/0098-3004(92)90029-Q

Jones L, Frechette J, Okal M, Kyle P, Oppenheimer C (2010) Terrestrial laser scanning (TLS) observations of the phonolite lava lake at Erebus volcano, Antarctica. Geol Soc Amer Ann Meet 42:177, Abstract with Program Jones L, Frechette J, Okal M, Kyle P, Oppenheimer C (2011) Observing the dynamics of Mount Erebus using a terrestrial-based LiDAR (abstract). Polar Technology Conference, Albuquerque 24 Mar 2011. http://polartechnologyconferenceorg/2011_pdf/PTC_2011_Jones.pdf.

Kelly PJ, Kyle PR, Dunbar NW, Sims KWW (2008) Geochemistry and mineralogy of the phonolite lava lake, Erebus volcano, Antarctica: 1972-2004 and comparison with older lavas. J Volcanol Geotherm Res 177:589-605

Martin RS, Roberts TJ, Mather TA, Pyle DM (2009) The implications of $\mathrm{H}_{2} \mathrm{~S}$ and $\mathrm{H}_{2}$ kinetic stability in high-T mixtures of magmatic and atmospheric gases for the production of oxidized trace species (e.g., BrO and NOx). Chem Geol 263:143-150. doi:16/j.chemgeo.2008.12.028

Novelli PC, Lang PM, Masarie KA, Hurst DF, Myers R, Elkins JW (1999) Molecular hydrogen in the troposphere: global distribution and budget. J Geophys Res 104:444

Oppenheimer C (2010) Ultraviolet sensing of volcanic sulfur emissions. Elements 6:87-92. doi:10.2113/gselements.6.2.87

Oppenheimer C, Kyle PR (2008) Probing the magma plumbing of Erebus volcano, Antarctica, by open-path FTIR spectroscopy of gas emissions. J Volcanol Geotherm Res 177:743-754

Oppenheimer C, Lomakina AS, Kyle PR, Kingsbury NG, Boichu M (2009) Pulsatory magma supply to a phonolite lava lake. Earth Planet Sci Lett 284:392-398

Oppenheimer C, Moretti R, Kyle PR, Eschenbacher A, Lowenstern JB, Hervig RL, Dunbar NW (2011) Mantle to surface degassing of alkalic magmas at Erebus volcano, Antarctica. Earth Planet Sci Lett 306:261-271. doi:10.1016/j.epsl.2011.04.005

Oppenheimer C, Fischer TP, Scaillet B (2012) Volcanic degassing: process and impact. Treatise on Geochemistry (in press)

Shinohara H, Matsushima N, Kazahaya K, Ohwada M (2011) Magma-hydrothermal system interaction inferred from volcanic gas measurements obtained during 20032008 at Meakandake volcano, Hokkaido. Japan Bull Volcanol 73:409-421.

doi:10.1007/s00445-011-0463-2 
Shinohara $H$ (2005) A new technique to estimate volcanic gas composition: plume measurements with a portable multi-sensor system. J Volcanol Geotherm Res 143:319-333. doi:16/j.jvolgeores.2004.12.004

Sweeney D, Kyle PR, Oppenheimer C (2008) Sulfur dioxide emissions and degassing behavior of Erebus volcano, Antarctica. J Volcanol Geotherm Res 177:725-733. doi:16/j.jvolgeores.2008.01.024

Wardell J, Kyle PR, Chaffin C (2004) Carbon dioxide and carbon monoxide emission rates from an alkaline intra-plate volcano: Mt. Erebus, Antarctica. J Volcanol Geotherm Res 131:109-121. doi:10.1016/S0377-0273(03)00320-2

Zreda-Gostynska G, Kyle P, Finnegan D, Prestbo K (1997) Volcanic gas emissions from Mount Erebus and their impact on the Antarctic environment. J Geophys Res 102:055 